\title{
Analyzing rainfall events and soil characteristics for water resources management in a canal irrigated area
}

\author{
K. G. Mandal*, J. Padhi, A. Kumar, D. K. Sahoo, P. Majhi, S. Ghosh, R. K. Mohanty, \\ M. Roychaudhuri
}

Directorate of Water Management (ICAR), Bhubaneswar, Odisha, India

Email address:

manda198kg@yahoo.co.in (K. G. Mandal)

\section{To cite this article:}

K. G. Mandal, J. Padhi, A. Kumar, D. K. Sahoo, P. Majhi, S. Ghosh, R. K. Mohanty, M. Roychaudhuri. Analyzing Rainfall Events and Soil Characteristics for Water Resources Management in a Canal Irrigated Area, Journal of Water Resources and Ocean Science. Vol. 2, No. 1, 2013, pp. 1-8. doi: 10.11648/j.wros.20130201.11

\begin{abstract}
Rainfall analysis is essential for water resources management and crop planning. An attempt has been made to analyse the rainfall of Daspalla region in Odisha, eastern India for prediction of monsoon and post-monsoon rainfall by using 6 different probability distribution functions, forecasting the probable date of onset and withdrawal of monsoon and finally crop planning for the region. Soil parameters were assessed for head, mid and tail reaches of the command area. Results revealed that, for prediction of monsoon and post-monsoon rainfall, Log Pearson Type-III and Gumbel distribution are found as the best fit probability distribution functions. The earliest and delayed most week of onset of rainy season was 20th SMW (14-20th May) and 25th SMW (18-24th June), respectively. Similarly, the earliest and delayed most week of cessation of rainy season was 39th SMW (24-30th September) and 47th SMW (19-25th November) respectively. The soils have the clay contents ranging from 29.6 to $48.8 \%$. The bulk density ranged from 1.44 to $1.72 \mathrm{Mg}$.m-3 irrespective of different sites. The saturated hydraulic conductivity decreased significantly with soil depth due to greater clay contents in lower layers; whereas water retention at field capacity and PWP increased significantly with increase in soil depths. Soil organic carbon varied from 0.34 to $0.95 \%$; it was the highest in the surface $(0-15 \mathrm{~cm})$ layer and then decreased down to the soil profile. The results of rainfall analyses and soil properties would help in management of rainfall and canal water in an effective way.
\end{abstract}

Keywords: Rainfall, Probability Distribution, Soil Analyses, Water Resources Management

\section{Introduction}

India ranks first among the countries that practice rainfed agriculture both in terms of extent (86 Mha) and value of production [1]. To meet the future food demands and growing competition for water among various sectors, a more efficient use of water in rainfed agriculture will be essential. Rain water management and its optimum utilization is a prime issue of present day research for sustainability of rainfed agriculture. To ensure water availability and dependability to all the farmers by proper utilization and conservation of rain water in storage tank during rainy season and by recycling the same for life saving irrigation during post rainy season. It is necessary that some storage tanks to harvest runoff and subsurface water are made in command area. This will reduce the risk of dry periods in cropping seasons and increase the production. Kothari et al. [2] opined that on the basis of water harvesting, water can be utilized for saving the crops during severe moisture stress and also to raise the post-monsoon crops thereby cropping intensity and net returns from the cultivated lands can be increased. In order to address the issue, detail knowledge of rainfall distribution can help in deciding the time of different agricultural operations and designing of water harvesting structures to meet out irrigation requirement [3, 4]. For sustainable crop planning, rainfall was characterized in term of its variability and probability distribution by many researchers $[5,6]$ for different places of India.

Odisha, an eastern Indian province, is mainly an agrarian state where about $70 \%$ of the population is engaged in agricultural activities and $50 \%$ of the state's economy comes from agricultural sector [7]. In order to stabilize the crop production at certain level, it is essential to plan agriculture on a scientific basis in terms of making best use of rainfall pattern of an area. This necessitates studying the sequences of dry and wet spells of an area so that necessary step can be taken up to prepare crop plan in rainfed regions. Scientific prediction of wet and dry spell analysis for proper crop planning may prove useful to farmers for improving prod- 
uctivity and cropping intensity and in turn their economic returns. Dry and wet spells could be used for analyzing rainfall data to obtain specific information needed for crop planning and also for carrying out agricultural operations.

The knowledge on soil properties viz. particle size distribution, bulk density, hydraulic properties, water retention characteristics is also essential for land use planning, water resources management $[8,9,10]$ in a canal irrigated commands. Assessment of soil water regime is an important step in making water management decisions [11].

Therefore, attempts were made to study the rainfall characteristics of canal irrigated area in the Daspalla block of Nayagarh district in Odisha, an eastern Indian state to manage the water resources for efficient crop planning. The soil characteristics are made to study the site-specific management of soils and crops, and also for development of water storage structures in the area.

\section{Materials and Methods}

\subsection{The Study Area}

The study was carried out in Kuanria Medium Irrigation Project (KIP) at Daspalla, Nayagarh district of Odisha (Fig. 1). It is located at $20^{\circ} 21^{\prime} \mathrm{N}$ latitude and $84^{\circ} 51^{\prime} \mathrm{E}$ longitude at an elevation of $122 \mathrm{~m}$ above mean sea level. The geographical area of Daspalla block is $571.57 \mathrm{~km} 2$. This study site comes under Agro-Eco Sub-Region 12.2 and Agro-Climatic Zone 7 according to NBSS\&LUP (ICAR) and Planning Commission, Govt. of India classification, respectively.

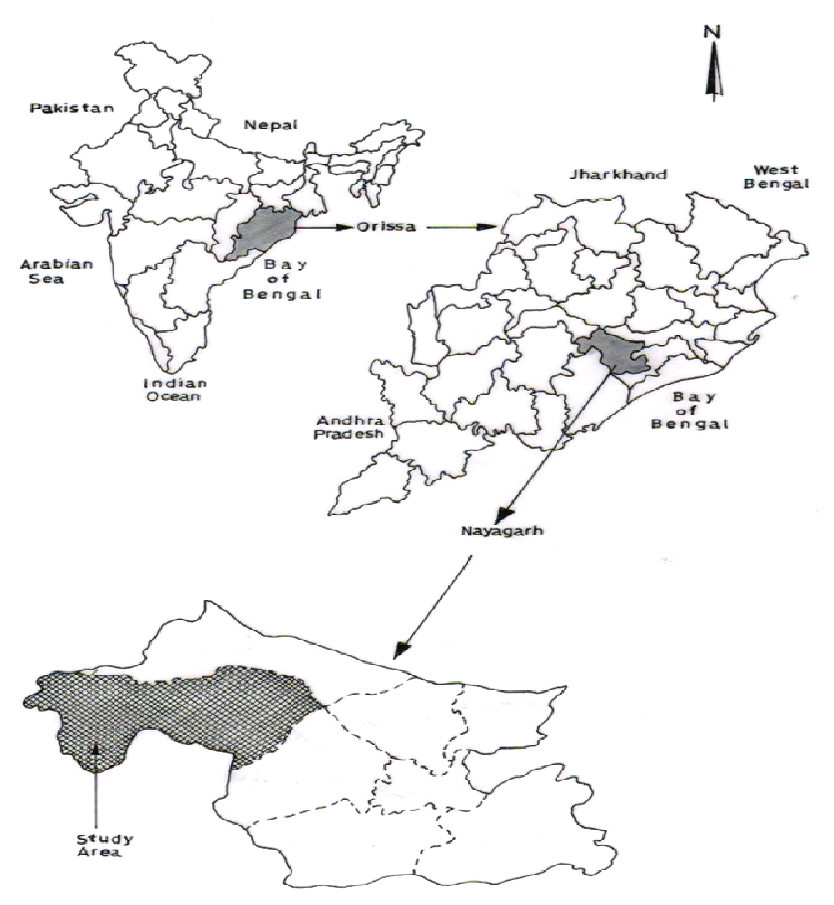

Figure 1. The study area i.e., Daspalla region of Nayagarh district in Odisha.

\subsection{Rainfall Data and Analyses Methods}

Rainfall data for years from 1995 to 2010 have been collected from meteorological observatory of Kuanria dam, Daspalla, Nayagarh. Rainfall data are categorized into four seasons such as pre-monsoon (March-May), monsoon (June-September), post-monsoon (October-December) and winter (January-February) season. The monthly effective rainfall was calculated using the equations 1 and 2 following USDA Soil Conservation Service method. The same method has been used for calculation of effective rainfall for rainfed districts of India by Sharma et al. [12].

$$
\begin{aligned}
& \mathrm{Pe}=\mathrm{Pt} / 125(125-0.2 \mathrm{Pt})(\text { when } \mathrm{Pt}<250 \mathrm{~mm}) \\
& \mathrm{Pe}=125+0.1 \mathrm{Pt}(\text { when } \mathrm{Pt}>250 \mathrm{~mm})
\end{aligned}
$$

where, $\mathrm{Pe}=$ monthly effective rainfall $(\mathrm{mm})$ and $\mathrm{Pt}=$ total monthly rainfall $(\mathrm{mm})$.

In this study, rainfall were predicted by six probability distribution functions (PDF) i.e. Normal, 2-Parameter Log Normal, 3-Parameter Log Normal, Pearson Type III, Log Pearson Type III and Gumbel distribution by using DISTRIB 2.13 component of SMADA 6.43 (Storm Water Management and Design Aid). Different probability distribution functions [13] are given as follows.

Normal distribution

$$
\mathrm{p}_{\mathrm{x}}(\mathrm{x})=\frac{1}{\sigma \sqrt{2 \pi}} e\left[-\frac{(x-\mu)^{2}}{2 \sigma^{2}}\right]
$$

where, $\mu=$ mean of the population of $x$ and $\sigma=$ variance of the population of $\mathrm{x}$.

Two-Parameter Log Normal distribution 


$$
p_{x}(y)=\frac{1}{\sigma_{y} \sqrt{2 \pi}} e\left[-\frac{\left(y-\mu_{y}\right)^{2}}{2 \sigma_{y}^{2}}\right]
$$

where, $y=\ln (x), \mu y=$ mean of the population of $y$ and $\sigma y$ $=$ variance of the population of $\mathrm{y}$.

Three-Parameter Log Normal distribution

$$
p_{x}(y)=\frac{1}{\sigma_{y} \sqrt{2 \pi}} e\left[-\frac{\left(y-\mu_{y}\right)^{2}}{2 \sigma_{y}^{2}}\right]
$$

where, $y=\ln (x-a), \mu y=$ mean of the population of $y$ and $\sigma y=$ variance of the population of $y$.

Pearson Type III distribution

$$
p_{x}(x)=p_{o}(1+x / \alpha)^{\alpha / \delta} e^{-x / \delta}
$$

where, $\delta=$ difference between mean and mode $(\delta=\mu-$ $\mathrm{Xm}), \mathrm{Xm}=$ mode of population $\mathrm{x}, \alpha=$ scale parameter of distribution, and $\mathrm{po}=$ value of $\mathrm{px}(\mathrm{x})$ at mode.

Log Pearson Type III distribution

$$
p_{x}(y)=p_{y o}(1+y / \alpha)^{\alpha / \delta y} e^{-y / \delta y}
$$

where, $\delta y=$ difference between mean and mode $(\delta y=\mu y$ - Ym), Ym = mode of population $\mathrm{y}, \alpha=$ scale parameter of distribution and pyo $=$ value of $p_{x}(y)$ at mode.

Gumbel distribution (also referred to as Fisher-Tippett Type I, Double Exponential, Gumbel Type I and Gumbel extremal distribution) is characterized by the probability density function,

$$
p_{x}(x)=\frac{\alpha}{\beta-\gamma}\left(\frac{x-\gamma}{\beta-\gamma}\right)^{\alpha-1} e\left[\frac{x-\gamma}{\beta-\gamma}\right]^{\alpha}
$$

where, $\alpha=$ scale parameter of distribution, and $\beta=$ location parameter of the distribution.

All six PDFs were compared by Chi-Square test for goodness of fit as given in the following equation.

$$
\chi 2=\sum \frac{(O-E)^{2}}{E}
$$

where, $\mathrm{O}$ is the observed value obtained by Weibul's method and $\mathrm{E}$ is the estimated value by probability distribution functions.

\subsection{Computation Method for Onset and Withdrawal of Rainy Season}

The onset and withdrawal of monsoon largely determine the success of rainfed agriculture. A prior knowledge of possible onset and withdrawal of effective monsoon is valuable in crop planning. Such knowledge in advance helps in deciding cropping pattern and choice of suitable crop varieties and also to plan comprehensive strategies for proper and efficient rainwater management for improving crop production per unit of available water [14]. Therefore, onset and withdrawal of rainy season was computed from weekly rainfall data by forward and backward accumulation methods as per the procedure suggested by Dash and Senapati
[15].

Each year is divided into 52 standard meteorological weeks (SMW). The first SMW of any year starts from 1-7th January and 52nd SMW is from 24-31st December. Weekly rainfall was summed by forward accumulation $(20+21+---$ +52 weeks) method until $75 \mathrm{~mm}$ of rainfall was accumulated. This $75 \mathrm{~mm}$ of rainfall has been considered as the onset time for sowing of rainfed crops [16]. The withdrawal of rainy season was determined by backward accumulation of rainfall $(48+47+46+\ldots+30$ weeks $)$ data. Twenty millimetres of rainfall accumulation was chosen for the withdrawal of the rainy season, which is sufficient for ploughing of fields after harvesting the crops $[17,18]$. The percent probability $(\mathrm{P})$ of each rank was calculated by arranging them in ascending order and by selecting highest rank allotted for particular week. The following Weibull's formula has been used for calculating percent probability.

$$
\mathrm{P}=(\mathrm{m} / \mathrm{N}+1) \times 100
$$

where, $\mathrm{m}$ is the rank number and $\mathrm{N}$ is the number of years of data used.

\subsection{Methods of Soil Sampling and Analyses}

Soil samples were collected from head, mid and tail reaches of the canal commands from different sites having cropping systems like rice-fallow, rice-sugarcane and rice-green gram etc. The exact location of different plots with respect to their latitude and longitude were measured with a GPS meter (model, Garmin eTrex Vista, Germany). Soil samples were collected during dry periods of the year 2010-11 and 2011-12. Samples were collected with the help of auger and down to the profile depth up to $90 \mathrm{~cm}$ from 5 different locations (5 x $5 \mathrm{~m}$ grid per sample) within one representative in a zig-zag pattern and also from four depth increments (i.e. $0-15,15-30,30-60$ and $60-90 \mathrm{~cm}$ ) from the soil profile to study the soil properties. Soil particle size distribution was determined by the hydrometer method [19] and soil texture class was determined by following the procedure of USDA classification. Soil $\mathrm{pH}$ was measured with the help of a digital $\mathrm{pH}$ meter (pHTestr30, Malaysia). Field capacity and permanent wilting point were determined by a pressure plate apparatus (Eijkelkamp, Model 505). The available water capacity (AWC, cm3.cm-3) of soils, expressed as volume of water per unit volume of soil, was estimated as the difference between field capacity (FC) and permanent wilting point (PWP). Saturated hydraulic conductivity (Ks) was measured by constant head method. Five replicates of bulk density ( $\mathrm{BD}$, expressed as $\mathrm{Mg} \mathrm{m}-3$ ) samples down to the profile depth up to $90 \mathrm{~cm}$ was also collected using soil cores and core samplers (Eijkelkemp Agrisearch Equipment) from four different layers and carried to laboratory. Organic carbon was determined by wet digestion method [20].

The analysis of variance technique was carried out on the data for each parameter as applicable to statistical design. The significance tests were carried out using appropriate 
standard methods.

\section{Results and Discussion}

\subsection{Annual Rainfall and Distribution over Seasons}

Total annual rainfall in Daspalla region ranged between 993.5 to $1901.8 \mathrm{~mm}$ with an average of $1509.2 \mathrm{~mm}$ and the coefficient of variation (CV) was $14.8 \%$. If rainfall received in a year was equal to or more than the average rainfall plus one standard deviation for 16 years of rainfall (i.e. $1509.2+223.8=1733 \mathrm{~mm})$. On four occasions $(1995,2001$, 2003 and 2008), this region had received rainfall of more than $1733 \mathrm{~mm}$; these years were considered as excess rainfall years. Only $25 \%$ of total years of analyses under this study had received rainfall of more than $1733 \mathrm{~mm}$ for this region. It is also observed that $44 \%$ of the total years of rainfall were below average $(1509.2 \mathrm{~mm})$ which were considered as the deficit rainfall years.

Monthly average and effective rainfall of Daspalla region for 16 years are presented in Fig. 2. It is revealed that, mean rainfall of July was $351.4 \mathrm{~mm}$, which was the highest and its contribution was $23.3 \%$ to the average annual rainfall (i.e. $1509.2 \mathrm{~mm}$ ). August rainfall was slightly lower than July rainfall (i.e. $20.6 \%$ of annual average rainfall). Average rainfall was lowest in the month of December. Total annual effective rainfall (ER) is $858.2 \mathrm{~mm}$ which is 56.9 percent of the total annual rainfall. Therefore, $651 \mathrm{~mm}$ of rainfall water is lost in the form of surface runoff, deep percolation and evaporation.

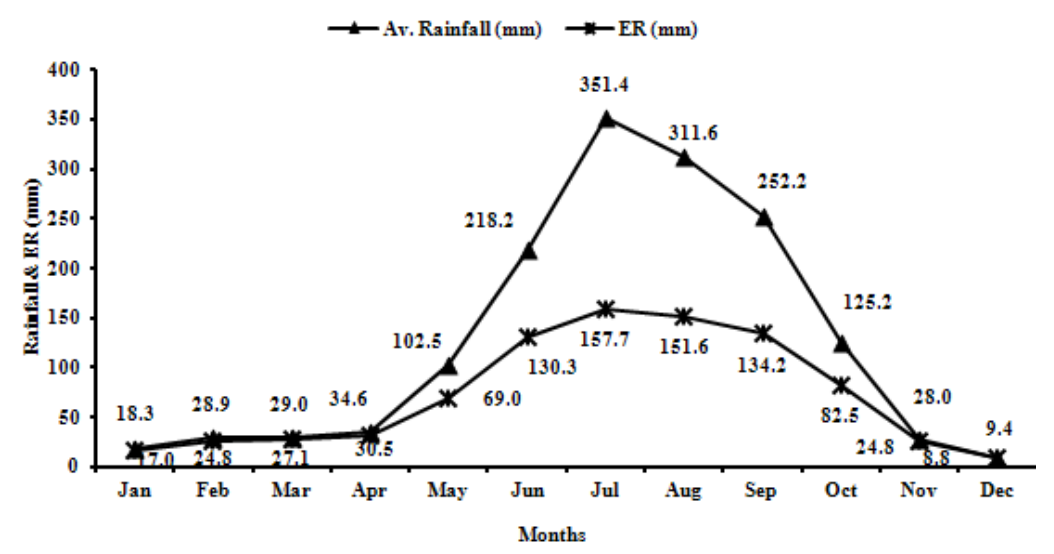

Figure 2. Long-term average monthly rainfall and effective rainfall for study area, Daspalla; ER is the effective rainfall.

The distribution of rainfall for different seasons from 1995-2010 is shown in Table 1. The normal southwest monsoon, which delivers about $75.7 \%$ of annual rainfall, extends from June to September. This is also the main season (rainy season) for cultivation of rainfed crops. The monsoon rainfall $(1133.3 \mathrm{~mm})$ is spreaded over a few rainy days with fewer rain events of high intensity. It causes surface runoff and temporary water stagnation in agricultural fields. Winter season contributes only $3.1 \%$ of the total annual rainfall; 10.8 and $10.4 \%$ of the total annual rainfall occurred during pre- and post-monsoon season, respectively.

Table 1. Rainfall distribution in Daspalla region over different seasons (data of 16 years for the period from 1995 to 2010).

\begin{tabular}{lll}
\hline Seasons & $\begin{array}{l}\text { Average } \\
\text { rainfall } \\
(\mathbf{m m})\end{array}$ & $\begin{array}{l}\text { Percentage } \\
\text { of total rainfall }\end{array}$ \\
\hline Pre-monsoon (Mar-May) & 166.1 & 10.8 \\
Monsoon (Jun-Sep) & 1133.3 & 75.7 \\
Post-monsoon (Oct-Dec) & 162.6 & 10.4 \\
Winter (Jan-Feb) & 47.2 & 3.1 \\
\hline
\end{tabular}

3.2. Prediction of Rainfall Using Probability Distribution

\section{Functions}

Annual rainfall for the region was predicted by using DISTRIB 2.13 component of SMADA 6.43 for 6 different probability distribution functions. Six predicted annual rainfall values were obtained for 6 PDFs by running DISTRIB 2.13. After that Chi-square value for each PDF was estimated by using equation 9. Chi-square values varied from 29.2 to 58.8 for 6 PDFs. Least Chi-square values were observed in Log Pearson Type III distribution for prediction of annual rainfall in Daspalla. Therefore, for this region, Log Pearson Type III considered as best fit PDF for prediction of annual rainfall. In this region, about $86 \%$ of the total annual rainfall occurs during monsoon and post-monsoon season and agriculture is totally dependent on the performance of south-west monsoon. Therefore, prediction of monsoon and post-monsoon rainfall is more important than annual rainfall for raising crops successfully with high and stable yields. For this reason, monsoon and post monsoon rainfall were predicted for 6 PDFs by running DISTRIB 2.13 and results are presented in Fig. 3 \& 4.

It is revealed that, during monsoon season, the observed monsoon rainfall was $1049.6 \mathrm{~mm}$ at $70 \%$ probability level and all the probability distribution functions predicted almost comparable rainfall. But in total, least Chi-square value was observed in Log Pearson Type III distribution. With 
regard to the post-monsoon rainfall, lowest Chi-square value was obtained in case of Gumbel distribution (Fig. 4). In this study, for prediction of monsoon and post-monsoon rainfall, Log Pearson Type III and Gumbel distribution are found as best fit PDFs. Observed rainfall at different probability levels for monsoon and post-monsoon months were determined by using Weibul's formula and presented in Table 2.

Table 2. Observed rainfall at different probability levels for monsoon and post- monsoon months.

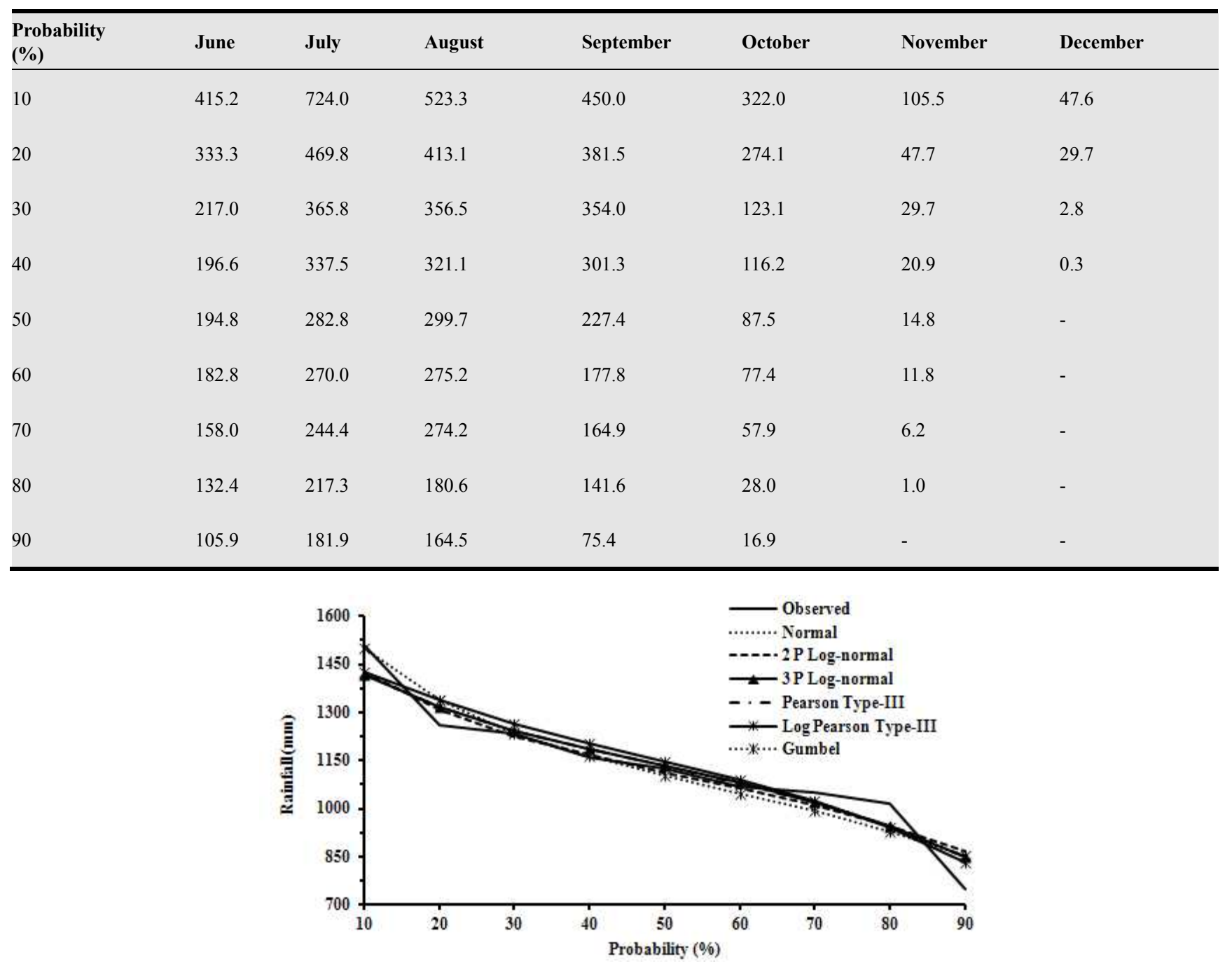

Figure 3. Observed and predicted rainfall $(\mathrm{mm})$ at different probability levels for the monsoon season.

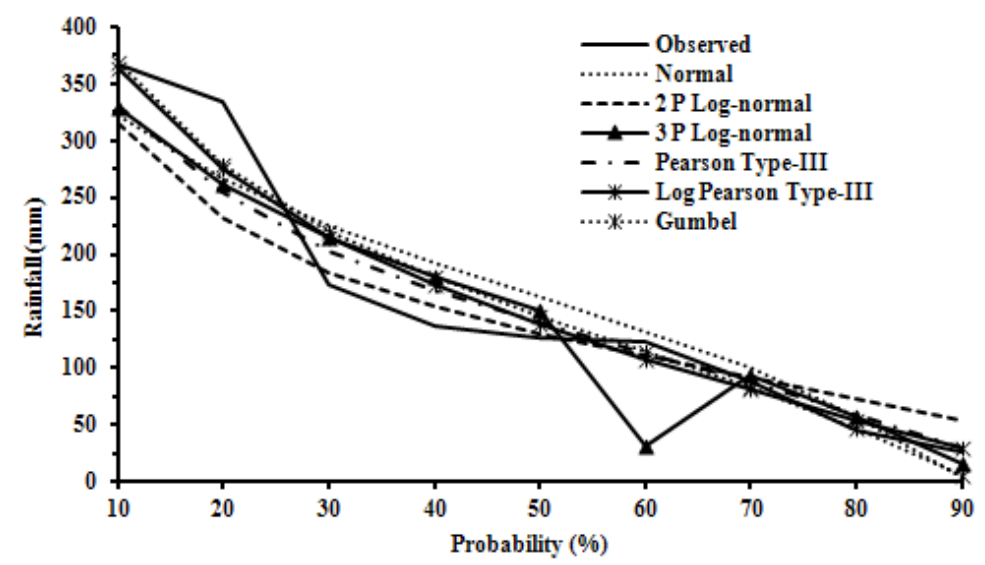

Figure 4. Observed and predicted rainfall $(\mathrm{mm})$ at different probability levels for post- monsoon season.

\subsection{Analyses of Rainfall for onset and Withdrawal of Monsoon Season}

The data on onset, withdrawal and duration of the rainy season (difference between onset and withdrawal time) and 
its variability in Daspalla region are presented in Table 3. Weekly rainfall data of 16 years (1995-2010) indicated that the monsoon starts effectively from 23rd SMW (4-10th June) and remains active up to 43rd SMW (22-28th October). Therefore, mean length of rainy season was found to be 21 weeks (147 days). The earliest and delayed week of onset of rainy season was 20th SMW (14-20th May) and 25th SMW (18-24th June), respectively. Similarly, the earliest and delayed week of cessation of rainy season was 39th SMW (24-30th September) and 47th SMW (19-25th November), respectively. The longest and shortest length of rainy season was coincided with 26 th and 17 th weeks, respectively. The probabilities of onset and withdrawal of rainy season was calculated by using Weibull's formula and results are presented in Table 4 . There is a $94 \%$ chance that the onset and withdrawal will occur during 25 th and 47 th SMW, respectively.

Table 3. Characterization of rainy season at the study site, Daspalla (1995-2010).

\begin{tabular}{|c|c|c|}
\hline Particulars & Week No. & Date \\
\hline Mean week of onset of rainy season & 23 & 4-10 June \\
\hline Earliest week of onset of rainy season & 20 & 14-20 May \\
\hline Delayed week of onset of rainy season & 25 & 18-24 June \\
\hline $\begin{array}{l}\text { Mean week of withdrawal of } \\
\text { rainy season }\end{array}$ & 43 & 22-28 October \\
\hline $\begin{array}{l}\text { Earliest week of withdrawal of } \\
\text { rainy season }\end{array}$ & 39 & 24-30 September \\
\hline $\begin{array}{l}\text { Delayed week of withdrawal of } \\
\text { rainy season }\end{array}$ & 47 & 19-25 November \\
\hline
\end{tabular}

Table 4. Soil properties of head reach soils in the right distributaries.

\begin{tabular}{|c|c|c|c|c|c|c|c|c|c|}
\hline $\begin{array}{l}\text { Soil } \\
\text { depth } \\
\text { cm }\end{array}$ & $\begin{array}{l}\text { Sand } \\
\%\end{array}$ & $\begin{array}{l}\text { dSilt } \\
\%\end{array}$ & $\begin{array}{l}\text { Clay } \\
\%\end{array}$ & $\begin{array}{l}\text { Tex- } \\
\text { tural } \\
\text { class }\end{array}$ & $\begin{array}{l}\text { Bulk } \\
\text { density } \\
\mathrm{Mg} \mathrm{m}^{-3}\end{array}$ & $\begin{array}{l}\text { EC } \\
d S / m\end{array}$ & pH & $\begin{array}{l}K_{\mathrm{s}} \\
\mathrm{cm} / \mathrm{hr}\end{array}$ & $\begin{array}{l}\text { SOC } \\
\%\end{array}$ \\
\hline $0-15$ & 66.6 & 5.7 & 27.7 & $\mathrm{scl}$ & 1.50 & 0.02 & 6.93 & 0.140 & 0.43 \\
\hline $15-30$ & 61.6 & 8.2 & 30.2 & $\mathrm{scl}$ & 1.48 & 0.01 & 7.64 & 0.128 & 0.24 \\
\hline $30-45$ & 56.6 & 8.2 & 35.2 & $\mathrm{sc}$ & 1.50 & 0.03 & 7.88 & 0.121 & 0.23 \\
\hline $45-60$ & 56.6 & 8.2 & 35.2 & $\mathrm{sc}$ & 1.48 & 0.02 & 7.91 & 0.103 & 0.21 \\
\hline $60-90$ & 61.6 & 3.2 & 35.2 & $\mathrm{sc}$ & 1.48 & 0.01 & 7.44 & 0.104 & 0.19 \\
\hline $90-120$ & 61.6 & 3.2 & 35.2 & $\mathrm{sc}$ & 1.50 & 0.06 & 7.71 & 0.100 & 0.14 \\
\hline
\end{tabular}

\subsection{Studies on Soil Characteristics of the Irrigated Com-} mand Area

\subsubsection{Head-reaches}

The soil properties in the head-reaches of right distributaries in the command area are determined and presented (Table 4). It is observed that, texture in the $0-30 \mathrm{~cm}$ soil layer was sandy clay loam while in other layers it was sandy clay in the head reach of the Kuanria command area. There was little variation of bulk density among different soil layers. $\mathrm{EC}$ values were quite less for all the soil layers (i.e. 0.01 to $0.06 \mathrm{dS} \mathrm{m}-1)$. Soil was slightly acidic to alkaline in nature. Soil organic carbon (SOC) content gradually decreased from top to bottom soil layers. Saturated hydraulic conductivity was highest for $0-15 \mathrm{~cm}$ soil layer and lowest for $90-120 \mathrm{~cm}$ depth of soil.

\subsubsection{Mid-reaches}

It is observed that, texture in the $0-15 \mathrm{~cm}$ soil layer was sandy clay loam; $15-45 \mathrm{~cm}$ soil layer clay loam while in other layers it was clay. Bulk density of the soil varied between 1.48 to $1.53 \mathrm{Mg} \mathrm{m}-3$ where as EC varied from 0.23 to $0.62 \mathrm{dS} \mathrm{m}-1$ in all the soil layers. In general, soil was slightly alkaline in nature and soil organic carbon (SOC) content varied between 0.27 and $0.67 \%$. Saturated hydraulic conductivity varied from 0.011 to $0.026 \mathrm{~cm} \mathrm{hr}-1$ for all the soil layers (Table 5).

Table 5. Soil properties of mid-reach command area under left distributaries.

\begin{tabular}{|c|c|c|c|c|c|c|c|c|c|}
\hline $\begin{array}{l}\text { Soil } \\
\text { depth } \\
\text { cm }\end{array}$ & $\begin{array}{l}\text { Sand } \\
\%\end{array}$ & $\begin{array}{l}\text { Silt } \\
\%\end{array}$ & $\begin{array}{l}\text { Clay } \\
\%\end{array}$ & $\begin{array}{l}\text { Tex- } \\
\text { tural } \\
\text { class }\end{array}$ & $\begin{array}{l}\text { Bulk } \\
\text { density } \\
\mathrm{Mg} \mathrm{m}^{-3}\end{array}$ & $\begin{array}{l}\text { EC } \\
d S / m\end{array}$ & pH & $\begin{array}{l}K_{s} \\
\mathrm{~cm} / \mathrm{hr}\end{array}$ & $\begin{array}{l}\text { SOC } \\
\%\end{array}$ \\
\hline $0-15$ & 48.4 & 16.8 & 34.8 & $\mathrm{scl}$ & 1.48 & 0.28 & 7.63 & 0.026 & 0.67 \\
\hline $15-30$ & 43.4 & 16.8 & 39.8 & $\mathrm{cl}$ & 1.48 & 0.23 & 7.96 & 0.018 & 0.49 \\
\hline $30-45$ & 43.4 & 16.8 & 39.8 & $\mathrm{cl}$ & 1.50 & 0.28 & 8.22 & 0.019 & 0.27 \\
\hline $45-60$ & 38.4 & 16.8 & 44.8 & c & 1.52 & 0.23 & 8.30 & 0.012 & 0.39 \\
\hline $60-90$ & 38.4 & 16.8 & 44.8 & $\mathrm{c}$ & 1.52 & 0.55 & 8.45 & 0.013 & 0.29 \\
\hline $90-120$ & 38.4 & 16.8 & 44.8 & c & 1.53 & 0.62 & 8.60 & 0.011 & 0.36 \\
\hline
\end{tabular}

\subsubsection{Tail-reaches}

The soils of tail end command areas were analyzed for determination of their physical and chemical properties, and are presented in Table 6 . There was a definite trend that sand content was greater in every soil layer than silt and clay contents, but there was slight difference in different layers of the soil profile. It is revealed that, soil was moderately alkaline in nature. The soil organic carbon (SOC) content decreased as soil depth increased for the site under WUA 5. Bulk density of soil varied between 1.41 to $1.47 \mathrm{Mg}$ m-3and EC varied between 0.01-0.11 dS m-1. Saturated hydraulic conductivity was highest in $0-15 \mathrm{~cm}$ soil layer and decreases towards lower depth of soil. 
Table 6. Soil properties of tail-reach command area in left distributaries.

\begin{tabular}{|c|c|c|c|c|c|c|c|c|c|}
\hline $\begin{array}{l}\text { Soil } \\
\text { depth } \\
\text { cm }\end{array}$ & $\begin{array}{l}\text { Sand } \\
\%\end{array}$ & $\begin{array}{l}\text { Silt } \\
\%\end{array}$ & $\begin{array}{l}\text { Clay } \\
\%\end{array}$ & $\begin{array}{l}\text { Tex- } \\
\text { tural } \\
\text { class }\end{array}$ & $\begin{array}{l}\text { Bulk } \\
\text { density } \\
\text { Mg m }^{-3} \\
\end{array}$ & $\begin{array}{l}\text { EC } \\
\text { dS/m }\end{array}$ & $\mathbf{p H}$ & $\begin{array}{l}K_{\mathrm{s}} \\
\mathrm{cm} / \mathrm{hr}\end{array}$ & $\begin{array}{l}\text { SOC } \\
\%\end{array}$ \\
\hline $0-15$ & 44.2 & 22.3 & 33.5 & $\mathrm{cl}$ & 1.41 & 0.11 & 8.15 & 0.023 & 0.58 \\
\hline $15-30$ & 44.9 & 22.8 & 32.3 & $\mathrm{cl}$ & 1.42 & 0.05 & 8.55 & 0.021 & 0.46 \\
\hline $30-45$ & 44.8 & 18.7 & 36.5 & $\mathrm{cl}$ & 1.44 & 0.05 & 8.50 & 0.022 & 0.39 \\
\hline $45-60$ & 43.5 & 9.7 & 46.8 & $\mathrm{c}$ & 1.45 & 0.01 & 8.54 & 0.017 & 0.39 \\
\hline $60-90$ & 41.8 & 8.9 & 49.3 & $\mathrm{c}$ & 1.46 & 0.01 & 8.53 & 0.015 & 0.33 \\
\hline $90-120$ & 44.3 & 8.7 & 47.0 & $\mathrm{c}$ & 1.47 & 0.02 & 8.45 & 0.014 & 0.29 \\
\hline
\end{tabular}

The soils in the tail reach of right distributaries are predominantly clay up to $45 \mathrm{~cm}$ soil depth and sandy clay in the $45-120 \mathrm{~cm}$ soil depths due to higher proportion of sand and clay contents (Table 6). Soil $\mathrm{pH}$ in this site was moderately alkaline. Bulk density of the soil increased gradually towards the lower depth of soil profile as amount of clay content was less in 45-120 soil depth in comparison to 0-45 $\mathrm{cm}$ soil depth. EC varied from 0.02-0.07 dS m-1 where as organic carbon (SOC) content varied between 0.23-0.39 percent. Saturated hydraulic conductivity was highest within 0-15 cm soil depth and lowest in 90-120 cm soil depth.

Saturated hydraulic conductivity values of tail reach soils of left distributaries were lower in comparison to tail reach soils of right distributaries. As the soil properties were different for head, mid and tail reach soils of left and right distributaries under Kuanria command area, different management of irrigation is required for optimal use of canal, rainfall and ground water. Through proper management, improvement of water productivity can be achieved.

\section{Conclusion}

The option to go for harvesting the rainfall is useful. Harvesting a small fraction of the excess rainfall and utilizing the same for supplemental irrigation to mitigate the impacts of devastating dry spells offer a good opportunity in the fragile rainfed regions. Based on experiences from watershed management research and large-scale development efforts, practical harvesting of runoff is possible only when the harvestable amount is more than $50 \mathrm{~mm}$ or greater than $10 \%$ of the seasonal rainfall. In this study area, as runoff amount was more than $10 \%$ of the seasonal rainfall, therefore practical harvesting of runoff is possible. Therefore, it is essential to construct water harvesting structures for conservation of rainfall and runoff water to ensure water availability and dependability to all farmers. Instead of growing rice, short duration and low water-requiring crops like groundnut, maize, sorghum, green gram, soybean, sunflower, field bean, cowpea and other low water required crops which have high return value can be grown during monsoon season. Pigeon pea is a very good crop for growing in this area under upland situation and on the bunds separated by rice fields. Another advantage of growing short duration cereals, pulses and oilseeds in the first fort-night of June is that these can be harvested by the end of September (39th SMW) and short duration post-monsoon crops can be sown during 40-43rd SMW (1-28th October). Since, post-monsoon rainfall is more uncertain and erratic than southwest monsoon, growing of high value post-monsoon crops without supplementary irrigation would be very risky. The significant contribution of weekly rainfall $(>46 \mathrm{~mm})$ during 36-40th SMW and high consecutive wet week probability during 36-40th SMW, there is a potential for harvesting excess runoff water for supplemental irrigations. Similarly, greater probabilities of consecutive dry weeks after 44th SMW, hints for need of supplementary irrigations and moisture conservation practices to be taken up. Even in the event of mid season dry weeks, mulching and other moisture conservation practices would help in reducing soil evaporation and conserve moisture in the soil.

The present study characterized the soil properties like particle size fractions, bulk density, saturated hydraulic conductivity, soil organic carbon and also $\mathrm{pH}$ for the cultivable area under Kuanria command area in Odisha, an eastern Indian state. This information will be useful for soil and water management decisions to be undertaken for the area. The measured soil properties and information would be utilized as input variables for many models for studying the changes in climate, soil hydraulic properties, soil environmental issues, water balance and solute transport etc. The organic carbon information would help for future planning on the cropping systems concerning carbon sequestration and policy making process for soil organic carbon restoration and other soil properties especially for the Kuanria command. Soil water retention is a major soil hydraulic property that governs soil functioning in ecosystems and greatly affects soil management. The information on Ks would be useful for making any decision for construction of water storage structure or open wells where water storage would be possible and better management of water would lead to better cropping practices.

\section{Acknowledgements}

Authors acknowledge the help and cooperation of Er. S.C. Sahoo, Kuanria Irrigation Sub-division Officer, Daspalla, Odisha, India. Authors are thankful to the INCID, Ministry of Water Resources, Govt. of India for providing financial support in carrying out the research work.

\section{References}

[1] B.R. Sharma, K.V. Rao, K.P.R. Vittal, Y.S. Ramakrishna and U. Amarasinghe, "Estimating the potential of rainfed agriculture in India: prospects of water productivity improvements”, Agric. Water Manage., 2010 97(1), pp. 23-30. 
[2] A.K. Kothari, M.L. Jat and J.K. Balyan, "Water balanced based crop planning for Bhilwara district of Rajasthan". Indian J. Soil Cons., 2007, 35(3), pp. 178-183.

[3] C. Prakash and D.H. Rao, " Frequency analysis of rainfall data for crop planning-Kota”. Indian J Soil Cons., 1996, 14(2), pp. 23-26.

[4] H.C. Sharma, H.S. Chauhan and Sewa Ram, "Probability analysis of rainfall for crop planning". J Agric. Engg 1979, 16(3), pp. 87-94.

[5] S. Mohanty, R.A. Marathe and S. Singh, "Probability models for prediction of annual maximum daily rainfall for Nagpur", J. Soil Water Cons., 2000, 44 (1\&2), pp. 38-40.

[6] R.S. Rana and D.R. Thakur, "Rainfall analysis for crop planning in Kulu valley, Himachal Pradesh", Indian J. Soil Cons., 1998, 26(2), pp.144-146.

[7] D. Panigrahi, P.K. Mohanty, M. Acharya and P.C. Senapati, "Optimal utilization of natural resources for agricultural sustainability in rainfed hill plateaus of Odisha", Agric Water Manage., 2010, 97, pp. 1006-1016.

[8] A. K. Singh, "Use of pedotransfer functions in crop growth simulations", J. Water Manag. 2000, 8, pp. 18-21.

[9] R. Kaur, S. Kumar, H.P. Gurung, J.S. Rawat, A.K. Singh, S. Prasad and G. Rawat,. "Evaluation of pedotransfer functions for predicting field capacity and wilting point soil moisture contents from routinely surveyed soil texture and organic carbon data", J. Indian Soc. Soil Sci., 2001, 50 (2), pp. 205-208.

[10] U.S. Saikia, and A.K. Singh, "Development and validation of pedotransfer functions for water retention, saturated hydraulic conductivity and aggregate stability of soils of Banha watershed”, J. Indian Soc. Soil Sci. 2003, 51, pp. 484-488.

[11] F. Ungaro, C. Calzolari, and E. Busoni, "Development of pedotransfer functions using a group method of data handling for the soil of the Pianura Padano-Veneta region of North Italy water retention properties", Geoderma., 2005, 124, pp. 293-317.

[12] D. Sharma and V. Kumar, "Prediction of onset and withdrawal of effective monsoon dates and subsequent dry spells in an arid region of Rajasthan", Indian J. Soil Cons., 2003, 31(3), pp. 223-228.

[13] V.T. Chow, "Hand Book of Applied Hydrology", Mc Graw Hills Book Company, 1964, New York.

[14] H.P. Das, R.S. Abhyankar, R.S. Bhagwal and A.S. Nair, "Fifty years of arid zone research in India", CAZRI, Jodhpur., 1998, pp. 417-422.

[15] M.K. Dash and P.C. Senapati, "Forecasting of dry and wet spell at Bhubaneswar for agricultural planning" Indian J. Soil Cons., 1992, 20(1\&2), pp. 75-82.

[16] B. Panigrahi and S.N. Panda, "Dry spell probability by Markov chain model and its application to crop planning in Kharagpur", Indian J. Soil Cons., 2002, 30(1), pp. 95-100.

[17] P.N. Babu and P. Lakshminarayana, "Rainfall analysis of a dry land water shed-Polkepad: A case study", J. Indian Water Res Soc., 1997, 17, pp. 34-38.

[18] G.V. Srinivasareddy, S.R. Bhaskar, R.C. Purohit and A.K. Chittora, "Markov chain model probability of dry, wet weeks and statistical analysis of weekly rainfall for agricultural planning at Bangalore", Karnataka J. Agric Sci., 2008, 21(1), pp. 12-16.

[19] G. J. A. Bouyoucous, "Recalibration of the hydrometer for making mechanical analysis of soil", Agron. J., 1951, 43, pp. 434-438.

[20] A. Walkley and I. A Black, "An examination of the method for determining soil organic matter and proposal modification of the chromic acid titration method", Soil Sci., 1934, 37 , pp. 29-38. 